\title{
Sediment characteristics and microbiological contamination of beach sand - A case-study in the archipelago of Madeira
}

\author{
Roberto Abreu ${ }^{a}$, Celso Figueira a,*, Daniela Romão ${ }^{\mathrm{b}}$, João Brandão ${ }^{\mathrm{b}}$, M. Conceição Freitas ${ }^{\mathrm{c}}$, César Andrade ${ }^{\mathrm{c}}$, \\ Graça Calado ${ }^{\mathrm{d}}$, Carmen Ferreira ${ }^{\mathrm{e}}$, Ana Campos ${ }^{\mathrm{e}}$, Susana Prada ${ }^{\mathrm{a}, \mathrm{f}}$ \\ a Faculdade de Ciências Exatas e da Engenharia da Universidade da Madeira, Campus Universitário da Penteada, 9000-390 Funchal, Madeira, Portugal \\ b Instituto Nacional de Saúde Dr. Ricardo Jorge, Avenida Padre Cruz, 1649-016 Lisboa, Portugal \\ c Faculdade de Ciências da Universidade de Lisboa, Instituto Dom Luis, Bloco C6, $3^{\circ}$ piso, Campo Grande, 1749-016 Lisboa, Portugal \\ d Laboratório de Saúde Pública, IASaúde, Rua das Pretas n 1, 9004-515 Funchal, Portugal \\ e Laboratório Regional de Veterinária e Segurança Alimentar, Caminho das Quebradas de Baixo n 79, 9000-254 Funchal, Portugal \\ f Centro de Vulcanologia e Avaliação de Riscos Geológicos, Universidade dos Açores, 9501-801 Ponta Delgada, Açores, Portugal
}

\section{H I G H L I G H T S}

- Microbial and granulometric data were analysed in Madeira archipelago sand beaches.

- Studies on the relationship between sand grain size and contamination are scarce.

- Artificial beaches revealed more susceptibility to microbiological contamination.

- Granulometric parameters are not linked to sand microbial contamination/persistence.

- Bather's presence and artificial nature explain sand contamination vulnerability.

\section{A R T I C L E I N F O}

\section{Article history:}

Received 7 April 2016

Received in revised form 21 August 2016

Accepted 22 August 2016

Available online $\mathrm{xxxx}$

Editor: D. Barcelo

\section{Keywords:}

Madeira

Beach sand quality

Mycological contamination
GRAPH ICAL A B S T RAC T

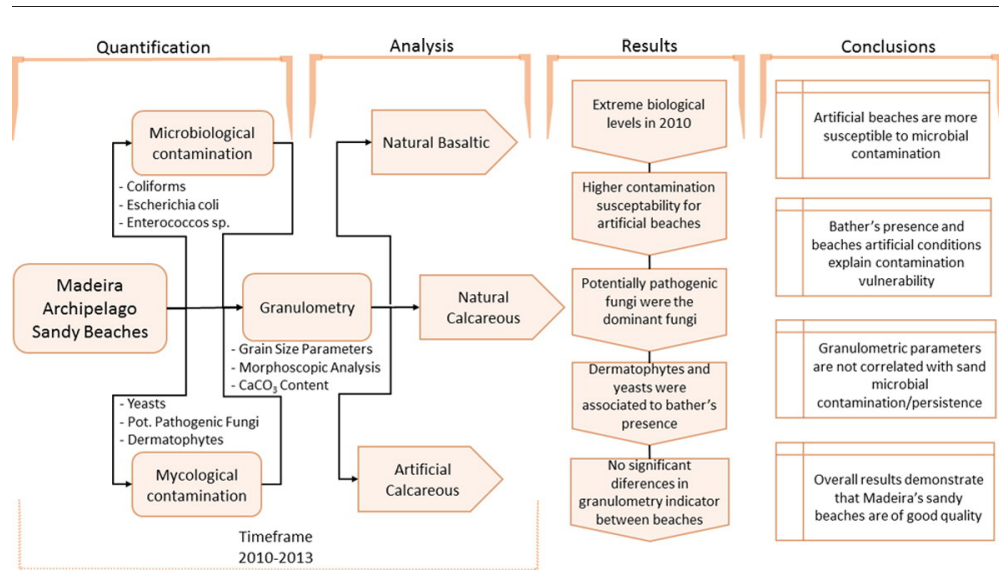

\footnotetext{
* Corresponding author.

E-mail address: celso.figueira@staff.uma.pt (C. Figueira).
} 
Bacteriological contamination Sand granulometry bather density and the influence of coastal protection structures needed to maintain the volume of artificial beach sand regarding the removal potential of wave induced currents are obvious influencing factors.

(C) 2016 Elsevier B.V. All rights reserved.

\section{Introduction}

Bathers have long enjoyed the physical and psychological benefits, of bathing in sandy beaches. This has generated, in many places, a considerable touristic revenue that has become important for the local economy. User perception of beach cleanliness is one of the main aspects that influence beach selection. Nevertheless, a clean beach does not always correlate with reduced health hazards, and microbiological quality of sand and water should be evaluated as a quality indicator (Botero et al., 2014; Elmir et al., 2007; Mansilha et al., 2009; Pereira et al., 2013).

At present Portuguese regulations and beach management practices focus essentially on microbial levels in water, this being the only indicator made available to users with regard to the quality of the beach. Sand is not incorporated within the regulatory analytical and informative framework in force (Pereira et al., 2013). Nevertheless, beach sand can create a suitable habitat for microorganisms and even provide the ideal conditions for them to prosper (Sabino et al., 2014; Whitman et al., 2014). Several studies demonstrate that harmful pathogens can be found in beach sand, which can also act as a reservoir (Abdelzaher et al., 2010; Fleisher et al., 2010; Goodwin et al., 2012; Sinigalliano et al., 2010; Yamahara et al., 2012). Whitman et al. (2014) compiles several studies where worldwide distributed pathogenic taxa in beach sands are identified. The prediction of which pathogens are present in a beach at a given time is, however difficult due to a high variety of sources (Shibata and Solo-Gabriele, 2012). The presence of indicator bacteria and potential pathogens is not limited to marine environments but also to freshwater beach sands (Abdelzaher et al., 2010; Hartz et al., 2008; Vogel et al., 2007). Examples of pathogenic bacteria in beach sand are Campylobacter (Khan et al., 2013), Salmonella (Yamahara et al., 2012), Vibrio vulnificus (Abdelzaher et al., 2010; Shah et al., 2011), Staphylococcus aureus (Plano et al., 2011) and faecal indicator bacteria (FBI) such as enterococci (Zhu et al., 2011). The source of faecal indicator bacteria in beach sand is uncertain, but exogenous sources (e.g., urban and/or agricultural runoff, sewage, warm-blooded domestic animals, and bathers) and/or indigenous sources (regrowth inside the sediments) can be considered as probable sources (Ferguson et al., 2005; Wright et al., 2009).

The highest concentration of faecal indicator bacteria can be found in the moister and cooler sands of foreshore or intertidal zones (Whitman et al., 2014). This is of particular importance as these are also the areas where bathers remain for the most time, especially infants, children and seniors, which comprise the most susceptible groups to infection (Pond, 2005). Regardless the source of contamination, the incidence of infection is higher in beachgoers relative to non-bathers (Fleisher et al., 2010; Sinigalliano et al., 2010), and higher between bathers who normally play in the sand, compared with those who do not (Heaney et al., 2012). Infants and children have a more active and frequent interaction with the sand, showing higher hand-to-mouth activity, which makes them more vulnerable to pathogen exposure. Digging in the sand is linked with a higher risk of diarrhoea and gastrointestinal disorders, and the risk for these illnesses is higher for children compared with adults (Heaney et al., 2009, 2012).

The growth and proliferation of microbes in beach sand is not restricted to bacteria. Several studies have detected different groups of fungi (yeasts, potentially pathogenic and allergenic fungi, and dermatophytes) in beach sands. As an example, Shah et al. (2011) reported Candida sp. in subtropical Miami Beach sand samples, and Vogel et al. (2007) detected the same species in South Florida (USA) beaches.
Also, fungi that can infect skin and nails (Microsporum sp. and Trichophyton sp.), among other less prevalent, yet still keratinophilic, fungal species such as Aspergillus sp., Fusarium sp., Scytalidium sp. and Scopulariopsis sp. for example, were found on the beaches of the Portuguese coast (Sabino et al., 2011). The presence of black mould, that may be responsible for allergies and subcutaneous and neurotropic infections, has also been reported (Efstratiou and Velegraki, 2010).

Granulometric parameters such as grain size distribution, (including symmetry of the grain size distribution curve) and composition, namely calcium carbonate $\left(\mathrm{CaCO}_{3}\right)$ content, which are influenced by sediment source processes involved in beach sediment transport, are expected to affect beach sand microbial numbers and establishment (Dale, 1974; Moreno et al., 2006). It has been documented that the presence and density of several FIB such as E. coli (Haller et al., 2009; Skalbeck et al., 2010), and enterococci (Gast et al., 2011; Phillips et al., 2011) in beach sand can be influenced by grain size parameters, and that the binding properties between sand particles and bacteria, are greatly dependent on the composition and on the size of the sand particles (Craig et al., 2002).

Microbiological communities in sand are increasingly getting more attention, both as a non-point source of water contamination (Yamahara et al., 2007), and as a stand-alone means of microbial contamination. Recently, a study from Honolulu, Hawaii, confirmed that faecal indicator bacteria survive longer in sand than in water, due to sunlight sheltering (Zhang et al., 2015). Overall, studies that address the issue of beach sand quality and monitoring are becoming more important, as public awareness rises and tourists increasingly value this as an important factor when choosing a holiday destination (Sabino et al. 2014). Recently, Solo-Gabriele et al. (2015), laid the foundations for standardized analytical methods, procedures and indicators of interest. Epidemiological studies to infer the actual influence of sand microbial flora on the health of beach users were also recommended.

Madeira archipelago has the particularity of having, within a small coastline, different types of beaches which contrast in the composition and texture of the sands. As such, it can be used as a case-study providing a basis for application in other beach destinations throughout the world (Pereira et al., 2013). In recent decades, tourism increased significantly in Madeira, and currently it provides $40 \%$ of Madeira's total income, with 5.9 million night stays in 2014 (Turismo de Portugal, 2015). As a region whose economy relies heavily on tourism, the conservation and quality of its beaches is crucial. Pereira et al. (2013) provides an important study regarding the microbiological and mycological quality of three different types of beach sand - natural basaltic, natural calcareous, artificial calcareous - occurring at the Portuguese volcanic islands of Madeira and Porto Santo. Despite the valuable contribution of that study in filling a gap in this scientific area, the time-span covered was seen by the authors as not sufficiently long to conclude on the significance of differences in bacterial and mycological indicator colony numbers found in sands from natural and artificial beaches. They explicitly refer the need for a larger set of data spanning a wider period of time.

This work intends to close that gap and provide an integrated analysis on the microbiological and mycological quality of three different types of beach sand of the Madeira region over a four year time window (2010-2013), as well as to investigate the relations between microorganisms and the nature of the sand. The objectives are to: 1) Quantify the microbial contamination of different beach sands in nearby beaches sharing a similar environment; 2) Relate microbial contamination with composition, grain size and sorting of beach sand, and with the 
environmental setting of the beach; 3) Analyse probable sources of sand pollution and the possible impact of inland-sourced extreme events, such as heavy rainfalls or flash floods, in sand contamination. These objectives were selected to provide a case-study on beach sand contamination, which could be of interest to the authorities responsible for the management of the beaches, not only in Madeira, but also worldwide.

\subsection{Madeira Archipelago}

The Madeira Archipelago is located in the North Atlantic Ocean, $850 \mathrm{~km}$ southwest of the Iberian Peninsula. It includes the main islands of Madeira and Porto Santo, as well as the Desertas and the Selvagens, two small groups of islands (Fig. 1).

Madeira is the largest, with $737 \mathrm{~km}^{2}$, and a maximum altitude of $1861 \mathrm{~m}$ above sea level (a.s.l.). Sandy beaches are rare in Madeira Island, and the most important example can be found in the Eastern sector of the island (Ponta de São Lourenço). The sediment of this small beach, only $100 \mathrm{~m}$ long, consists of a mixture of basaltic and biocalcarenite particles (Brum da Silveira et al., 2010). Apart from this, there are also a few natural black basaltic sand beaches (Praia Formosa, Praia da Laje and Porto da Cruz). This sand is essentially composed by basaltic lithoclasts mixed with some small shell fragments. As a way to increase the number of sand beaches on the island and to meet touristic and local demand, three artificial beaches have been built in the south coast of Madeira island - Calheta east and Calheta west in 2005, and Machico (Praia da Banda D'Além) in 2008 - using carbonate rich imported yellow sand.

Porto Santo is a smaller, and older volcanic island, with $43 \mathrm{~km}^{2}$ and maximum altitude of $517 \mathrm{~m}$ a.s.l. According to Johnson et al. (2011), and based on existing bathymetry, this deeply eroded island, has currently about one third of its original area. The presence of an extensive submerged insular platform that became exposed during glacial periods is in the origin of the abundant calcareous-rich organogenic sand deposits that form its famous $9 \mathrm{~km}$-long golden sand beach along the island's southern coast (Czajkowski, 2002). The sand of Porto Santo beach is essentially biogenic and calcareous, over $80 \%$ of sand particles consisting of $\mathrm{CaCO}_{3}$. The sand grains indicate a primary marine and organic source: they consist essentially of fragments of calcareous algae, echinoderms, bryozoans, molluscs, and marine gastropods fossils together with volcanic lithoclasts and mineroclasts (5-20\%), and a residual fraction of recent shell fragments (Andrade et al., 2008). The sand is considered fine to medium grained, moderately well sorted (Andrade et al., 2008).

\section{Methodology}

\subsection{Sand sampling}

Eight beaches were sampled in Madeira Island, among which 5 are natural and made of basaltic sand, and 3 are artificial and made of imported calcareous sand. The Praia da Laje (northwest) and Praia do Porto da Cruz (northeast) beaches are the only ones located in the northern coast of the island (Fig. 1).

In Porto Santo, seven beaches were sampled. Although in geological and geomorphological terms, the Porto Santo beach is a 9 km-long continuous natural beach made of yellow calcareous sand, it is administratively divided into seven sections/bathing beaches for management purposes and all of them were sampled (Fig. 1).

Samples for sedimentological characterization were obtained in August 2008 (Porto Santo beaches) and October 2013 (Madeira beaches). Three samples of superficial sand $(<10 \mathrm{~cm}$ depth) was retrieved from the beach face, at mid-tide level, and then mixed together in order to obtain a composite sample.

Samples for microbiological analyses were taken on the area of the beach where beachgoers presence is higher (the beach berm), which also corresponds to the areas where the sand is drier and less influenced by tides and waves (reduced sand washing effect). In order to obtain a representative sample of the entire length of the beach, three sand samples were collected at a depth of 5-15 cm, in three equidistant points aligned parallel to the tideline, so as to obtain a single $200 \mathrm{~g}$ composite sample. The sampling depth was considered adequate to maintain the moisture content, and guarantee sufficient microorganism protection from surface temperature and sunlight irradiation. Field sampling was

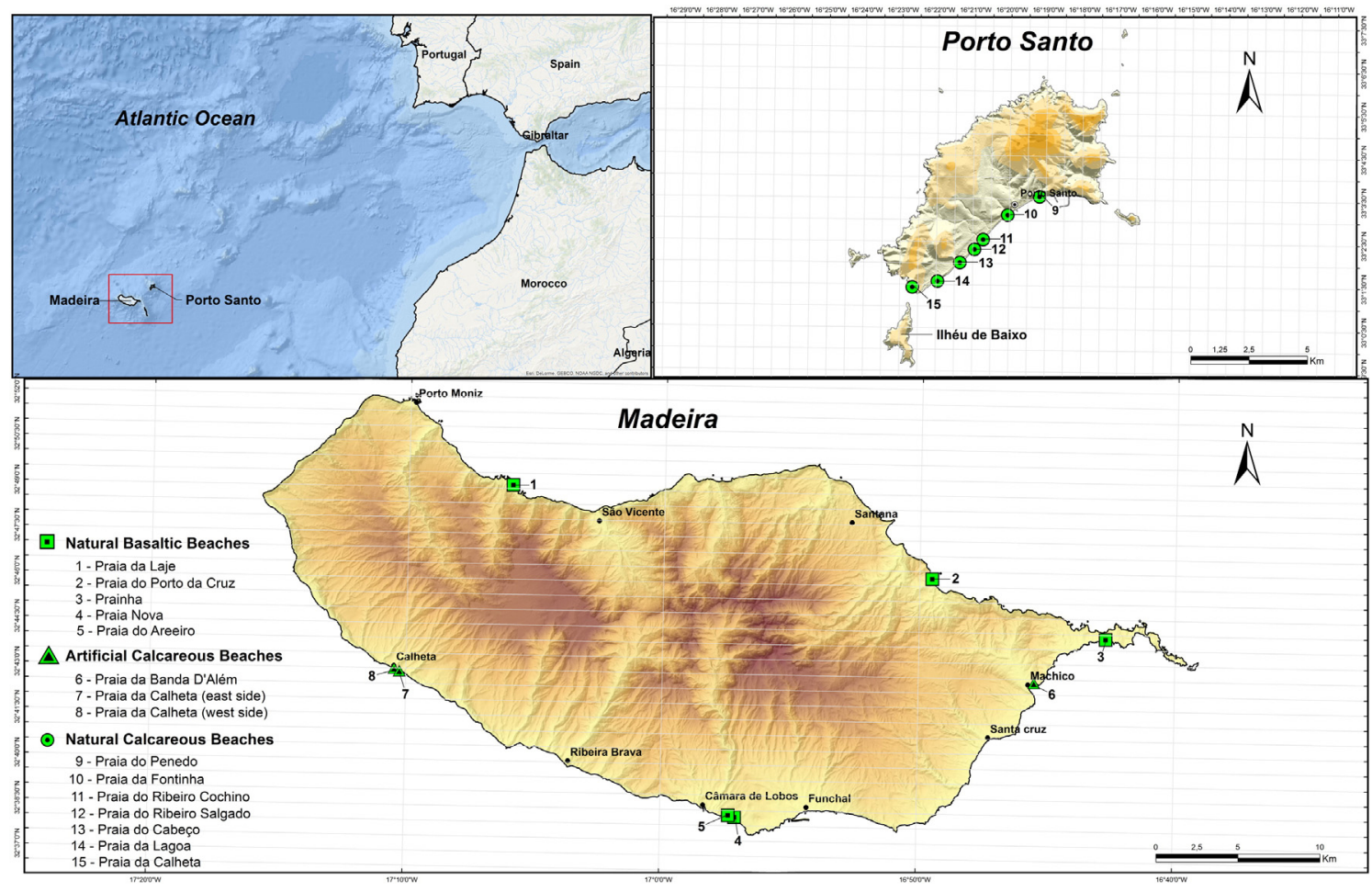

Fig. 1. Madeira archipelago geographical framework and location of the analysed beaches in the islands of Madeira and Porto Santo. 
executed monthly throughout the bathing season- June to September in 2010, 2011, 2012 and 2013 (4 months in each year). July 2013 samples collected for fungi were not considered due to technical complications. Samples were taken using sterilized and thermal bags and gloves, labelled and transported in a cold environment and with light restrictions. Samples were analysed instantly after arriving at the laboratory, and then further split for bacteriological and mycological analysis.

\subsection{Sedimentological analysis}

In the laboratory, each sample was washed with tap water and ovendried at $100{ }^{\circ} \mathrm{C}$. At least $100 \mathrm{~g}$ of material were processed for grain size using a series of standard sieves ( -5 to $4 \varphi ; 32.0$ to $0.0625 \mathrm{~mm}$, at $0.5 \varphi$ intervals). The software GRANGRAF (Carvalho, 1998) was used for computing statistical parameters on central tendency, sorting, symmetry and kurtosis, following the graphic method (Folk and Ward, 1957). The dimensional and sorting classification followed Friedman and Sanders (1978) and the symmetry and kurtosis classification followed Folk and Ward (1957). The $1 \varphi$ fraction of each sample was analysed under the binocular microscope in order to qualitatively characterize its composition.

\subsection{Microbial analysis}

A small sample ( $50 \mathrm{~g}$ ) of each bulk sample was moved to a Pyrex glass flask which contained $500 \mathrm{~mL}$ of sterilized distilled water. A magnetic stirrer was added to the sample and then the sample was strongly stirred $(500 \mathrm{rpm})$ for $30 \mathrm{~min}$, in order to maximize the transfer of the bacteria existing in the sand into the suspension.

A small portion of the suspended material ( $10 \mathrm{~mL}$ was then extracted and added to a $120 \mathrm{~mL}$ sterilized PET container (IDEXX), and filled with sterilized distilled water until it reached $100 \mathrm{~mL}$. Subsequently, two dehydrated culture media were added to the solution: Colilert (IDEXX) for coliforms and E. coli detection, Enterolert (IDEXX) for enterococci, and, before being properly homogenized, they were left resting for $5 \mathrm{~min}$. The solution was then moved and sealed in a Quantitray (IDEXX), and then placed in the incubator at $37 \pm 0.2{ }^{\circ} \mathrm{C}$ for $18-22 \mathrm{~h}$, for coliform and $E$. coli detection, and at $41 \pm 0.5^{\circ} \mathrm{C}$ for $24-28 \mathrm{~h}$ for intestinal enterococci detection. The bacteria quantification was performed using a MPN table for total bacteria, and the results articulated are given in colony forming units per gram of sand ( $\mathrm{cfu} / \mathrm{g})$. E. coli and coliforms detection was performed through positive well's counting, under ultraviolet light $(\lambda=360 \mathrm{~nm})$.

\subsection{Mycological analysis}

Fungi presence was determined by the spread plate method using a selective culture media (Brandão et al., 2002). A sample of $40 \mathrm{~g}$ was weighted on a precision scale and transferred to a sterile flask container (Pyrex) to which had been previously added $40 \mathrm{~mL}$ of sterilized distilled water. The stirring was performed in a Titramax 100 stirrer at $70 \mathrm{rpm}$ for $30 \mathrm{~min}$, in order to prevent damage to the fungi hyphae reproductive structures and consequent loss of viability as well as to guarantee an effective washing of the sand. Table 1 shows the fungi that were analysed in our study.

A small portion of the solution $(0.5 \mathrm{~mL}$ for each duplicate) was then selected and applied in:

Table 1

Fungi subject to laboratory analysis.

\begin{tabular}{ll}
\hline Yeasts & Candida sp. \\
Dermatophytes & Tricophyton sp. \\
Potentially pathogenic & Penicillium sp.; Aspergillus fumigatus; Aspergillus \\
and/or allergenic fungi & niger; Aspergillus sp.; Cladosporium sp.; Paecylomices \\
& sp.; Curvularia sp.; Fusarium sp.; Mucor sp.; \\
& Geotrichum sp.; Acremonium sp.; sterile mycelia \\
\hline
\end{tabular}

1. Two Petri dishes containing malt extract agar with a selective medium (Chloramphenicol) for potentially pathogenic and/or allergenic fungi detection, and then incubated at $27.5 \pm 2{ }^{\circ} \mathrm{C}$ for $5-7$ days;

2. Two agar plates with a selective dermatophyte medium (Dermasol), then incubated at $27.5 \pm 2{ }^{\circ} \mathrm{C}$ for $15-20$ days.

Subsequently, a colony count was executed on both samples. Yeasts were accounted in both culture media. Fungi growing in malt agar media were considered to be potentially pathogenic and/or allergenic fungi. Dermatophytes were identified as white coloured colonies against a yellowish background, in Dermasol media. Fungi identification was performed by observing the fungi reproductive and vegetative (mycelia) structures with lactophenol blue solution prepared in mounted slides under the microscope. These laboratory procedures were performed in a certified laboratory (NP EN ISO/IEC 17025:2005) by proficient and qualified technicians. In both replicas, the number of identical taxa/species colonies was summed, so that $1 \mathrm{~mL}$ of the suspension could be matched with $1 \mathrm{~g}$ of sampled sand with the final results expressed in colony forming units per gram of sand ( $\mathrm{cfu} / \mathrm{g}$ ).

\subsection{Data analysis}

All statistical analyses were performed with $I B M{ }^{\circledR}$ SPSS ${ }^{\circledR}$ Statistics 22, Inc. The microbiological data collected during the 4 sampling periods (June, July, August and September of 2010-13) in the 3 types of sand beaches (artificial, basaltic and calcareous) were analysed by KruskalWallis Independent Samples test. The level of significance $(p)$ was calculated and $p<0.05$ was regarded as significant. These tests were conducted considering month, sand type and year, separately, for bacteriological and mycological data, followed by an overview of all the collected data considering the same parameters. The same statistical analysis was done in order to assess the possible differences between different sedimentology factors (kurtosis, sorting, skewness and mean diameter). Table 2 summarizes the statistical analysis performed.

Graphs describing sedimentology parameters were designed taking into account the data collected and identified from the three sand types, and not from each beach individually. Mean and standard deviation were performed to demonstrate the mineral percentage of each sand type.

\section{Results and discussion}

\subsection{Bacteriological analysis}

July 2010 is the month with the highest values for coliforms and enterococci. In this same year, and after the first summer months (June and July), these microorganisms reduced their presence and maintained a low incidence. After the 2010 peak, E. coli was not detected in our samples until August 2012, after which it experienced a reduction over the following months. Although with a continuous, but discrete presence

Table 2

Statistical analysis.

\begin{tabular}{ll}
\hline $\begin{array}{l}\text { Comparison } \\
\text { parameters }\end{array}$ & Analyses description \\
\hline $\begin{array}{c}\text { Monthly } \\
\text { variation } \\
\text { Annual variation }\end{array}$ & $\begin{array}{l}\text { Comparison between the microbial load found in each month, } \\
\text { independent of year of sampling or sand type. } \\
\text { Cand type } \\
\text { variation } \\
\text { independent of month of sampling or sand type. } \\
\text { Comparison between the microbial load found in each sand } \\
\text { type, independent of month or year of sampling. } \\
\text { Comparison between the three main grain characteristics } \\
\text { (mean diameter, sorting, skewness and kurtosis) considering } \\
\text { the three types of sand, independent of month or year of } \\
\text { sampling. }\end{array}$ \\
\hline
\end{tabular}




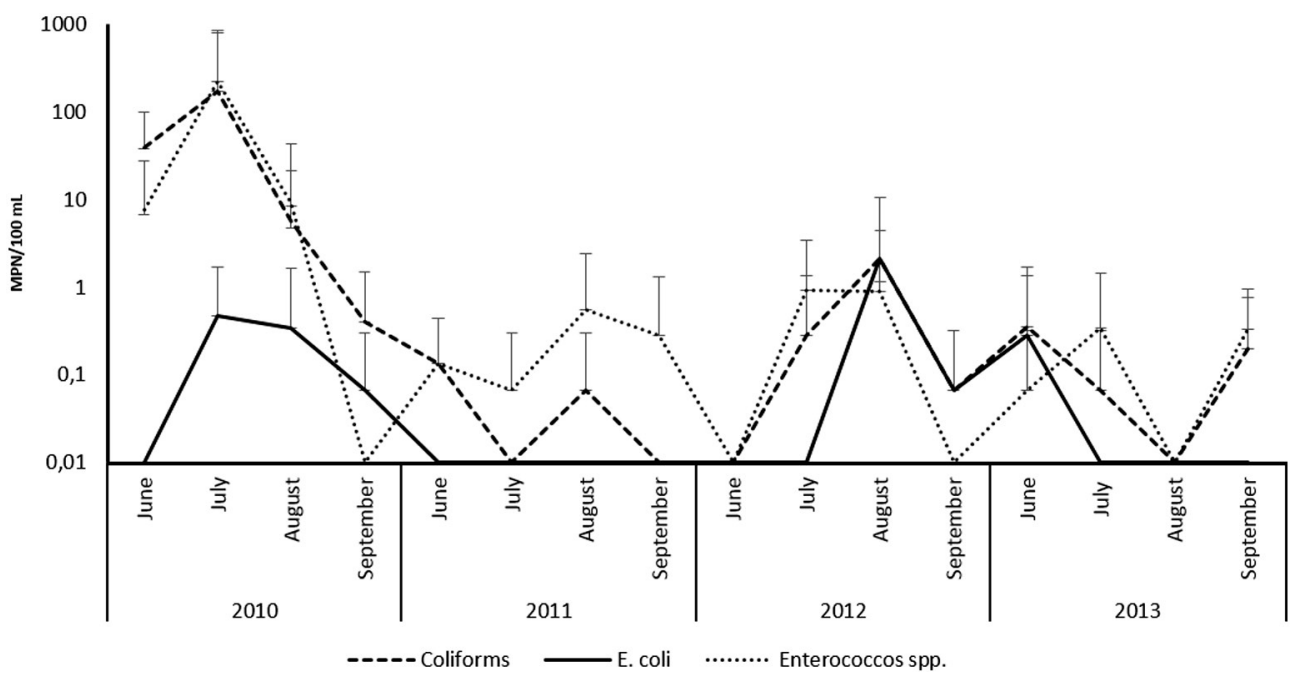

Fig. 2. Monthly bacteria average variation in the 2010-2013 time frame.

throughout the years, faecal coliforms and enterococci showed similar variations (Fig. 2).

Kruskal-Wallis independent sample test showed no significant differences in the distribution of the bacteria over the monthly averages $(p=0.98)$, even though the data values from July displayed a deviation from the average, visible when considering the deviation from the mean (Fig. 3). This is most probably, due to the high values from the samples collected during July 2010. In spite of this deviation, there are no indications that the month factor has an impact on the distribution of bacterial load.

Annual trends showed high values in 2010, and a gradual decrease throughout the years, with a small occurrence for bacteria in the following years. The exception was E. coli, whose values were higher in 2012. (Fig. 4). The Kruskal-Wallis test shows significant differences in the distribution of the different bacteria groups during the study time frame $(p=0.00)$ (Fig. 5). It is possible to observe that each year had fluctuations that separated them from the year before, especially when considering 2010 and, although in a more subtle way, 2012 (Fig. 4). Even so, values collected during 2010 showed a higher amount of variation (Fig. 2), thus reinforcing the idea that this might have been an unusual year. This had been previously observed by Pereira et al. (2013), but this study emphasizes its exceptionality since in the subsequent years such high values of microbiological sand contamination did not occur. The 2010 values were originally explained by an extreme flash flood

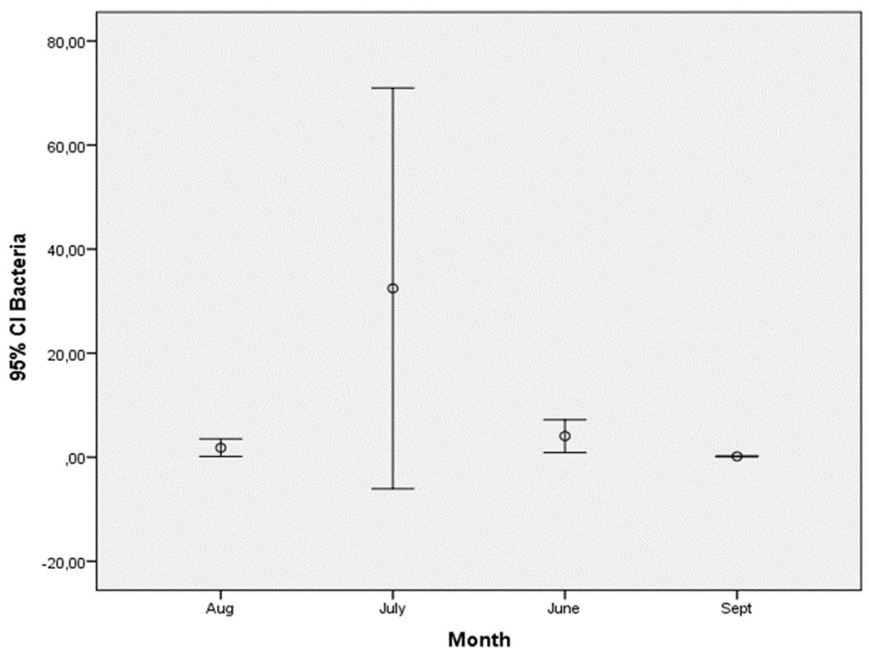

Fig. 3. Statistical output of Bacteria vs. month. event occurred on February 20 of that year, but, as the authors stated, this could only be confirmed through more data gathering. According to Pereira et al. (2013), Madeira's geographic features, namely beach characteristics, outflows from damaged sewer lines, and stranded wreckages that resulted from the flash-flood event were responsible for high levels of FIB in 2010. Furthermore, the perceived sharp decline on bacteriological figures throughout the 2010 summer months (July and August), and in the following years seem to have been the result of infrastructure rebuilding and debris removal. This seems to support the fact that it was the 2010 extreme rainfall and flash flood event that skewed the statistical data.

In most cases, and reinforcing Pereira et al. (2013) findings, our figures confirm enterococci levels to be higher than E. coli throughout the study time frame (Fig. 2). This dominance/presence may be related to the fact that enterococci appear to be more resilient to environmental factors when compared to E. coli (Whitman et al., 2014). The higher enterococci resistance is related with several abiotic factors such as moisture and rainfall (Byappanahalli and Fujioka, 2004), solar radiation and temperature (Mika et al., 2009), pH, detergents and salinity (Pereira et al., 2013). The monthly analysis of E. coli and enterococci show higher values during the hottest summer months (July and August), with a decrease in cooler months (Fig. 2), which suggests that temperature may influence microbiological presence/persistence in Madeira's beach sand, in accordance with what is also documented by Whitman and Nevers (2003) and Whitman et al. (2014). Other studies also suggest that higher temperatures could stimulate an increase in E. coli and enterococci concentrations in summer months, (Ishii et al., 2007; Zehms et al., 2008; Zhang et al., 2015). Other non-point sources of faecal contamination such as wildlife should not be dismissed, due to their significant contribution of faecal bacteria on beach sand (Elmir et al., 2007). In a relevant study, dog faeces far exceed enterococci contribution when compared to human and bird inputs in sand (Wright et al., 2009). Nevertheless, empirical observations of the sampled beaches of Madeira show that dogs have a minor presence in beaches due to stringent regulations.

\subsection{Mycological analysis}

Potentially pathogenic fungi were the better represented group throughout the study time frame. Dermatophytes were only detected in June 2010, August 2010 and 2011, and September 2012. Yeasts showed higher presence in July and September 2010, and June 2012 (Fig. 6).

The independent sample test showed that there are no significant differences in the monthly distribution of the fungi $(p=0.87)$. The 


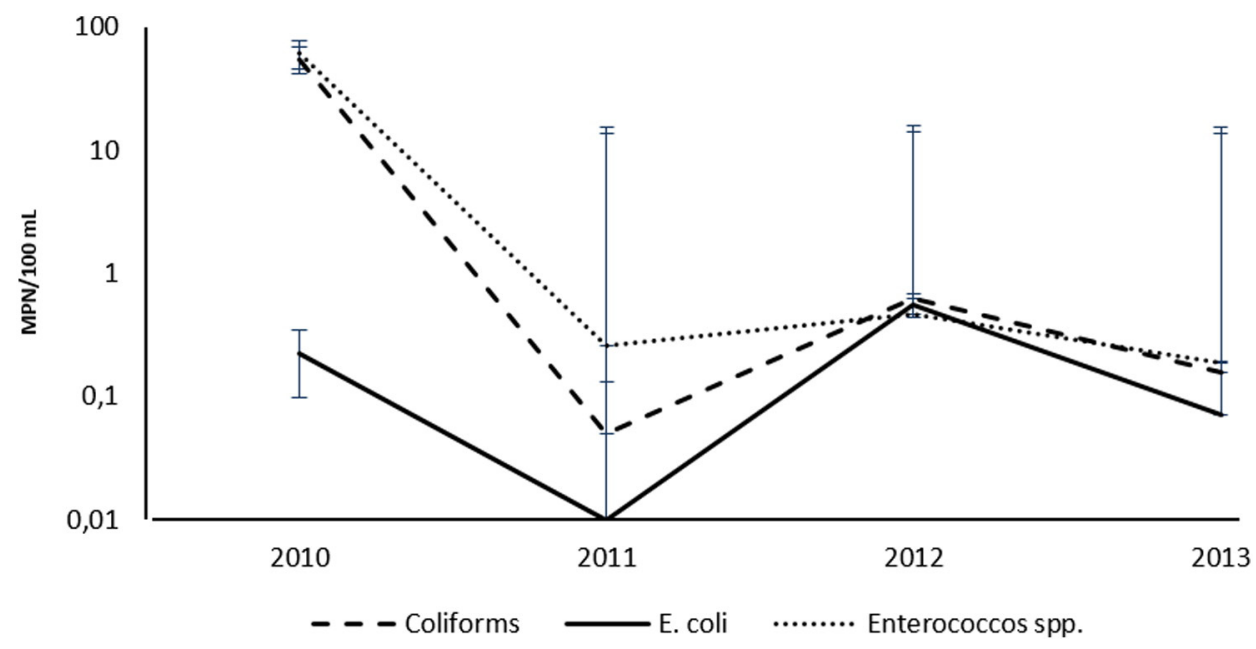

Fig. 4. Annual bacteria average variation in the 2010-2013 time frame.

mycological load had fewer fluctuations over the months when compared with the bacterial load. The deviation from the mean values is very similar throughout the different months (Fig. 7).

Differences between years show a regular presence of potential pathogenic fungi along the study time frame. Also, and after experiencing high values in 2010, yeasts and dermatophytes experienced a decline over the years, with the exception of yeasts that saw a slight increase from 2011 to 2012 (Fig. 8). Kruskal-Wallis independent sample test, with the sampling data grouped by year, revealed significant differences between years and the distribution of different fungi in those years $(p=0.00)$ (Fig. 9). The reason why this occurs is, most likely, due to the data fluctuations being high for each year and not necessarily because there's one particular year that stands out from the other, as observed in the bacterial samples.

An overall statistical monthly analysis indicated lack of significance ( $p=0.87$ ) between the fungal loads found in the sampled months. However, from the visual analysis of the complete dataset, July was the month with highest deviations when related to the average. Despite this fact, the deviation observed was not sufficient to reject the hypothesis that the distribution of fungi load is similar between months. Annual analysis showed a significant difference $(p=0.00)$ in fungi distribution in the different years. Besides, the annual analysis shows, empirically, that the fungi load differs greatly between the different sampling years, even if we ignore the year 2010. Taking this into

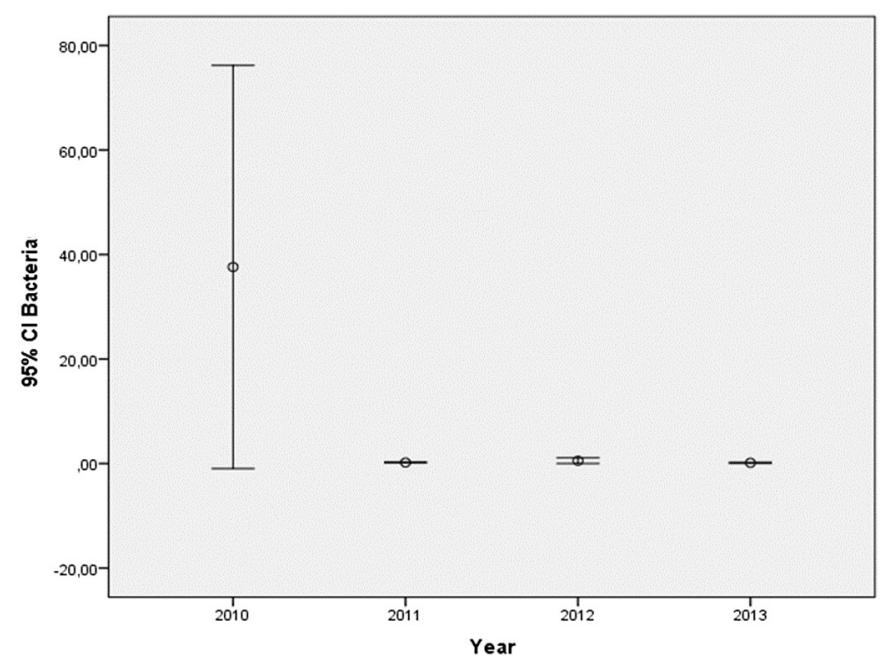

Fig. 5. Statistical output of Bacteria vs. year. account, the year 2010 seems to be much more atypical when considering bacterial load than when considering fungi load.

The annual distribution of fungi demonstrates elevated figures in 2010 and a slight decline in the following years for yeasts and dermatophytes (Fig. 8). Again, the extreme rainfall and flash flood event can be invoked to support this pattern of variation. Potential pathogenic fungi, such as saprophytic ones, were the most common fungi detected in Madeira and Porto Santo beaches and their values were rather constant throughout the study time-frame (Fig. 6). This seems to indicate that they are part of the natural biological communities of these beaches. Identical outcomes were also obtained in several other works. Sharaf (2005) found high rates of the genus Aspergillus spp., Fusarium sp., and Cladosporium sp. in Egyptian black sand. In Portuguese beaches, despite the presence of a high percentage of unidentified sterile mycelia, Penicillium sp. and Cladosporium sp. were the most common fungi detected in the samples (Azevedo et al., 2010). This predominance was, also, detected in Brazilian beaches (Gomes et al., 2008; De Moura Sarquis and De Oliveira, 1996) where Aspergillus sp., Penicillium sp., and Fusarium sp. the dominant fungi in sand. In Italian beaches, in addition to the above mentioned species, Salvo and Fabiano (2007) study showed the dominance of also Cladosporium sp. and Acremonium sp. in beach sand. Because of its involvement in several human diseases (Kaštelan et al., 2014), some of these ubiquitous fungal genera are considered clinically relevant (Velonakis et al., 2014; Wang et al., 2014).

The presence of yeasts in Madeira and Porto Santo beaches (Fig. 6) can be also linked to bather's presence, which is supported by several works (Brandão et al., 2002; Whitman et al., 2014). In fact, due to Madeira warm climate, which provides a consistent presence of bathers during the summer months, yeast presence was, with some variations, constant, while in 2013 there was the exception with no records in the sampled months. Our study only acknowledged the Candida sp. genus, an opportunistic pathogen commonly associated with cutaneous, oral, and vaginal infections in humans (Ferreira et al., 2000; Velonakis et al., 2014). When associated with a variety of terrestrial and aquatic substrates, can be regarded as indicators of pollution (Vogel et al., 2007).

Dermatophytes are detected in our study only in the months when beachgoers presence/attendance is normally high (June and August 2010, August 2011, and September 2012 - Fig. 6). This reinforces Pereira et al. (2013) conclusions of a strong correlation between beachgoers and dermatophytes presence. Our data also support Pereira et al. (2013) remarks about the absence of variability on the number of bathers through the sampled years. Several authors suggest that the identified dermatophyte genus Trichophyton sp. (Fig. 6) known as an agent of human and animal contamination (Salvo and Fabiano, 2007; 


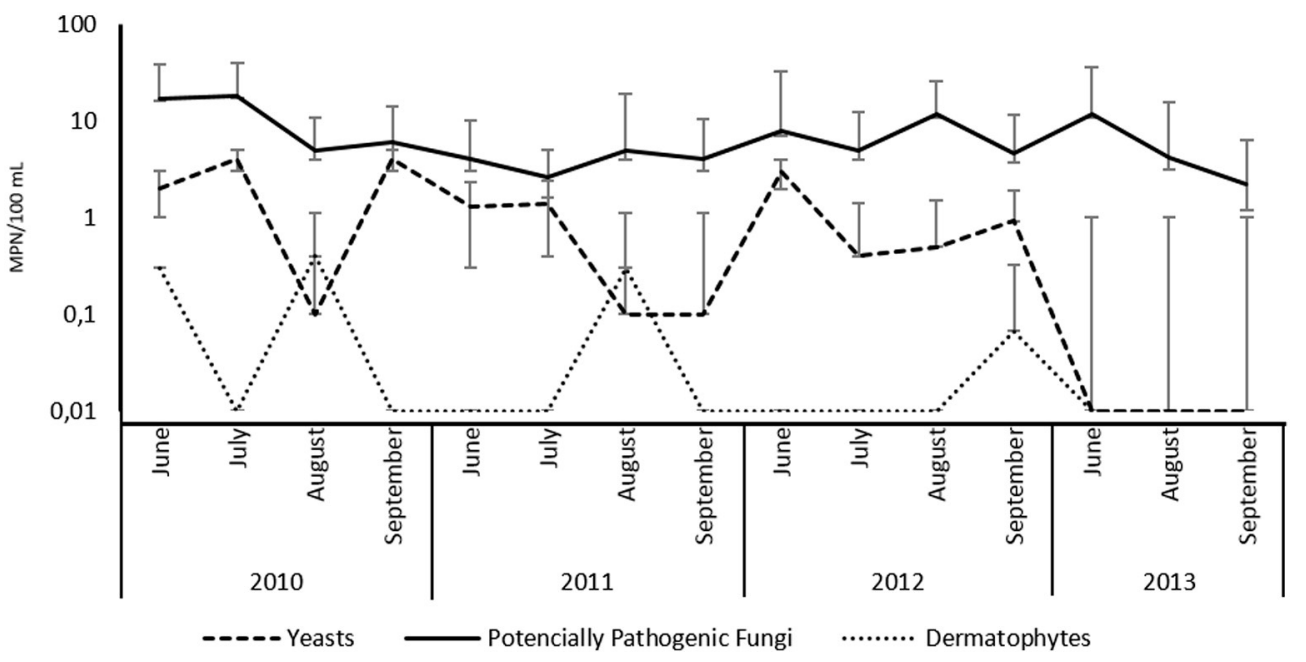

Fig. 6. Monthly fungi average variation in the 2010-2013 time frame.

Ulfig et al., 1997), is correlated with anthropogenic and animal presence (Arvanitidou et al., 2002; Resell and Taplin, 1970, Sabino et al., 2011.

\subsection{Beach sand grain size analysis}

\subsubsection{Sand characteristics}

Grain size and morphoscopic results, as well as $\mathrm{CaCO}_{3}$ content are presented in Fig. 10, Fig. 11, Fig. 12, and Fig. 13, respectively.

Madeira natural basaltic beaches are made of medium to coarse sand, moderately to very well sorted, showing a size gradient between Praia Nova and Prainha (west to east in both coasts) from coarser and less sorted to finer and better sorted. The grain size curves show mesokurtic distributions $\left(0.9<\mathrm{K}_{\mathrm{G}}<1.11\right)$, and only Praia do Porto da Cruz yielded a leptokurtic distribution $\left(1.1<\mathrm{K}_{\mathrm{G}}<1.5\right)$. Fragments of volcanic rocks are the main components of these sediments. Prainha is the only beach exhibiting $\mathrm{CaCO}_{3}$ content ( $9 \%$ ), which reflects the presence of bioclasts inherited from the nearby Plio-Pleistocene Ponta de S. Lourenço calcareous sand dunes (Galopim De Carvalho and Brandão, 1991).

Madeira artificial calcareous beaches were constructed with sand imported from Morocco and are composed by moderately sorted medium to fine sands, positively and negatively skewed, with platikurtic curves $\left(0.67<\mathrm{K}_{\mathrm{G}}<0.90\right)$. The exception is Praia da Banda D'Além,

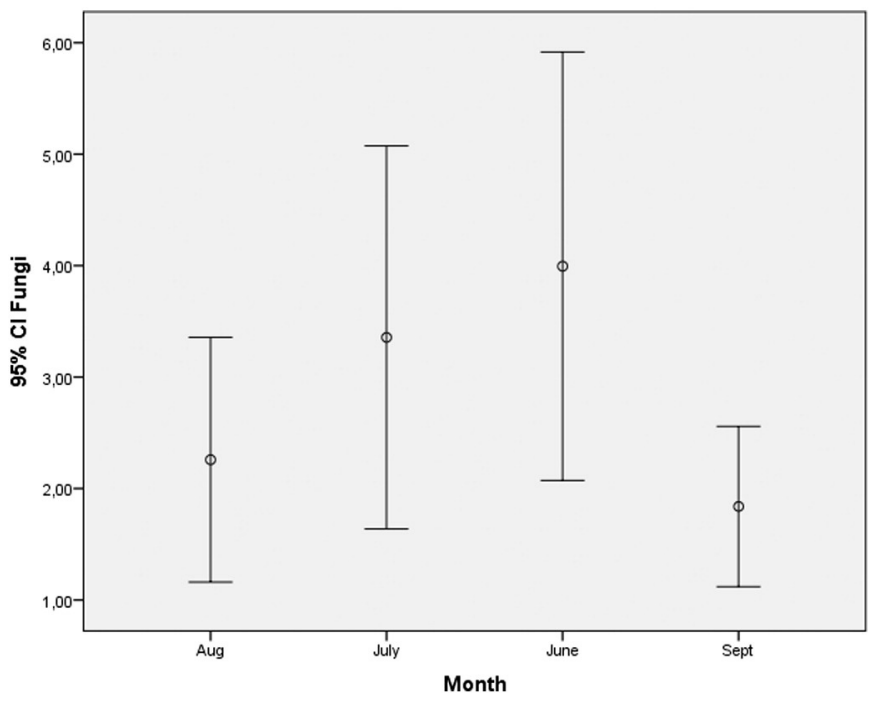

Fig. 7. Statistical output of Fungi vs. month. with mesokurtic distribution $\left(0.9<\mathrm{K}_{\mathrm{G}}<1.11\right)$. The $\mathrm{CaCO}_{3}$ content in these sands correspond to 40 to $50 \%$ of the total sample, essentially due to the presence of bioclasts most probably from Plio-Pleistocenic source rocks, contemporary shell fragments, and different species of foraminifera. The Praia da Banda D'Além shows a lower content in volcanic rock fragments relatively to Calheta (east and west) and this is interpreted as the latter beach sand having been placed more recently. These lithic fragments represent the solid contribution supplied by Madeira's rivulets to the exotic sand after their placement and, as such, it is expected that the most recent beaches have the lowest proportion of local sediments. This beach sand displays very negative skewness values indicating a particle size distribution with excess of coarse elements in relation to a normal distribution, which is typical in natural beach environments. In Calheta (east side) the proportion of hyaline quartz grains (with and without iron coating) is higher than in the other two artificial beaches.

Porto Santo natural calcareous beaches are very similar to each other and are characterized by well sorted medium to fine sands, mainly symmetrical. The exception is Praia da Calheta, in the west tip of Porto Santo bay, which is coarser, poorly sorted and very negatively skewed. The $\mathrm{CaCO}_{3}$ content is around 90\%, except in Praia da Calheta where it drops to $75 \%$, indicating relevance of terrigenous sources. Within the $0-1 \varphi$ size fraction modern bioclasts, and bioclasts inherited from the quaternary beach rock/aeolianite outcrops typical of Porto Santo, are present in similar proportions, however, the latter predominate in smaller size fraction. Praia da Calheta is the only beach where the proportion of volcanic rocks fragments exceeds the bioclasts content. Kurtosis analysis shows mesokurtic dominance $\left(0.9<\mathrm{K}_{\mathrm{G}}<1.11\right)$ among these beach sands, with the exception of Praia da Calheta and Praia da Fontinha that show leptokurtic distributions $\left(1.1<\mathrm{K}_{\mathrm{G}}<1.5\right)$.

\subsubsection{Relationship between beach, beach sand and microbial contamination}

Kruskal-Wallis independent sample tests, when analysing the microbiological loads with the type of beaches, revealed significant differences $(p=0.00)$ among the fungi load present in the different types of sand. The same test was performed for bacterial load, and it was observed that the type of sand had no impact in the existence and distribution of bacterial amount ( $p=0.058$ ). Even so, the $p$ value obtained for the bacterial load analysis is close to the limit value, and when considering the distribution around the mean values, it is clear that the artificial sand shows a higher deviation when compared to the natural beach sand. Therefore, the distribution of values around the average suggests that artificial beaches have a higher potential to shelter a larger microbiological load. 


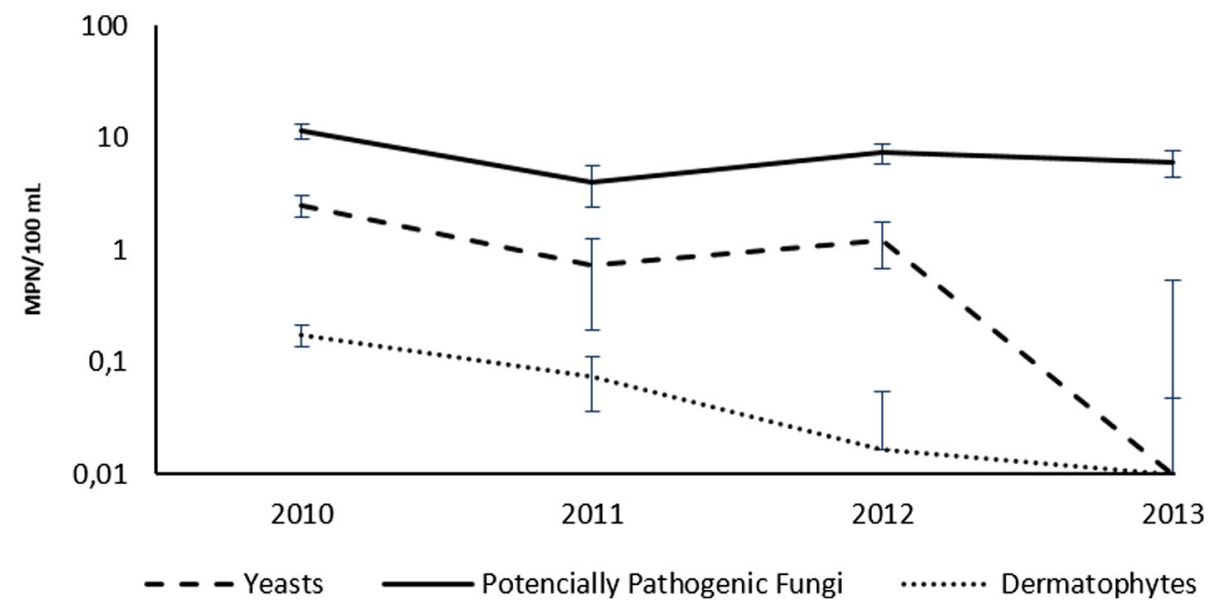

Fig. 8. - Annual fungi average variation in the 2010-2013 time frame.

Identical statistical analysis was performed to investigate possible differences between grain size distributions (measured using distribution parameters - mean diameter, sorting, skewness and kurtosis) within the different sand types. The results revealed similarities in terms of mean diameter $(p=0.09)$, sorting $(p=0.06)$, and skewness $(p=$ 0.18 ) between sand from the different beaches. Kurtosis was the only sedimentological indicator yielding significant differences $(p=0.024)$ among the sampled beaches. Regarding this parameter, artificial beaches were the ones that showed higher deviations from the average. This was expected since only three beaches have artificial sand and all of them scored below 0.96 in the kurtosis parameter, in comparison with natural beach sands that scored above this value, the only exception being Praia Nova. Artificial beaches have a stronger mineralogical similarity with natural calcareous beaches. On the opposite side, natural basaltic beaches are the most different from every other sand types (Fig. 12).

All other sedimentological parameters, shows that they are very similar to each other, despite the sand origin. The only parameter challenging this statement is kurtosis, which is a descriptor of the shape of the probability distribution. Higher kurtosis values (leptokurtic curves) indicate that most of the size variance is the result of infrequent extreme deviations, as opposed to frequent modestly sized deviations (platikurtic curves). This factor affects the distribution and dispersion of value curves, and does not seem to affect the bioburden.

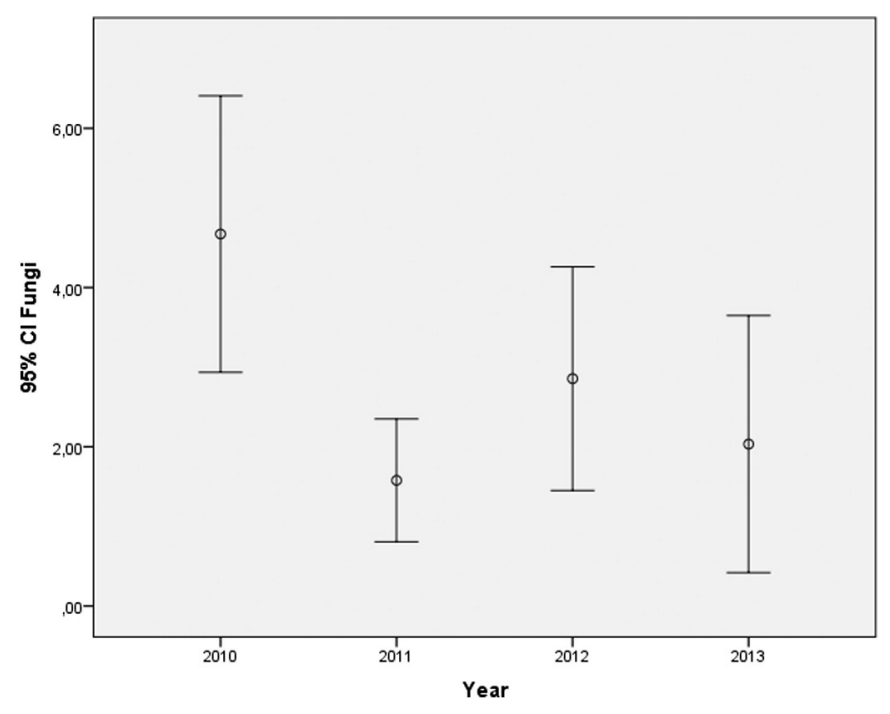

Fig. 9. Statistical output of Fungi vs. year.
Since there seems to be no textual pattern distinguishing natural and artificial beach sands, there are no reasons to believe that grain size distribution is effective in modulating the differences found in the microbial load found between the two major sand type groups: natural and artificial. These results show that there is no robust correlation between the sedimentological characteristics and microbial loads in the beaches sampled in Madeira and Porto Santo. Even though there are differences in contamination between different beaches, the physical characteristics of sand grains do not show important differences between each other.

This suggests, contrary to other works (Sessisch et al., 2001; Velonakis et al., 2014), that the nature of the sand is not a relevant factor regulating microbiological quality/quantity, at least in Madeira Archipelago. This seems to further support that, in Madeira, high contamination levels are most probably related with geographical and morphological features, wind regime and/or bather's density in the artificial beaches, rather than with sedimentological features.

Sea water also cannot be ruled out as a potential source of sand contamination. Phillips et al. (2011) stated the relevant relationship between average beach sand quality and sea water, linking levels of enterococci in sand with sea water.

Statistical analysis suggests higher microbial contamination trends in artificial sand beaches when compared with natural ones, especially when focusing on the fungal load, since no statistical significance was found for bacterial load. Nevertheless when analysing the graphs representing mean and standard deviation (Fig. 14) it is clear that the higher deviations from central values characterize the artificial sand type beaches.

This may be explained by several factors. Sea birds could be viewed as promoting sand contamination (Hernandez et al., 2014; Whitman et al., 2014) as they are responsible for high $E$. coli concentrations on foreshore sand (Whitman and Nevers, 2003), and elevated enterococci values in beach sand (Bonilla et al., 2007; Piggot et al., 2012). Although bird faecal droppings are known as one of the main causes of high faecal indicator levels in beach sand, bird presence, in our sampled beaches, is occasional, and normally only by isolated individuals. The imported sand (from Laayoune, Western Sahara) could have acted as a source of exotic contaminants with invasive potential. However, this introduction was done several years ago, and contaminant levels would have already diminished and should not be any different from local conditions (Defeo et al., 2009). A more plausible cause for this situation is the impact that artificial structures built to protect artificial beaches from erosion have on coastal currents and dynamics (Lee et al., 2006). The beaches had to be protected by groins and submarine breakwaters to avoid removal of the artificially placed sand by both longshore and cross-shore waveinduced currents. This lead to reduced turbulence and decreased currents intensities, resulting in small renewal rates of both water and 

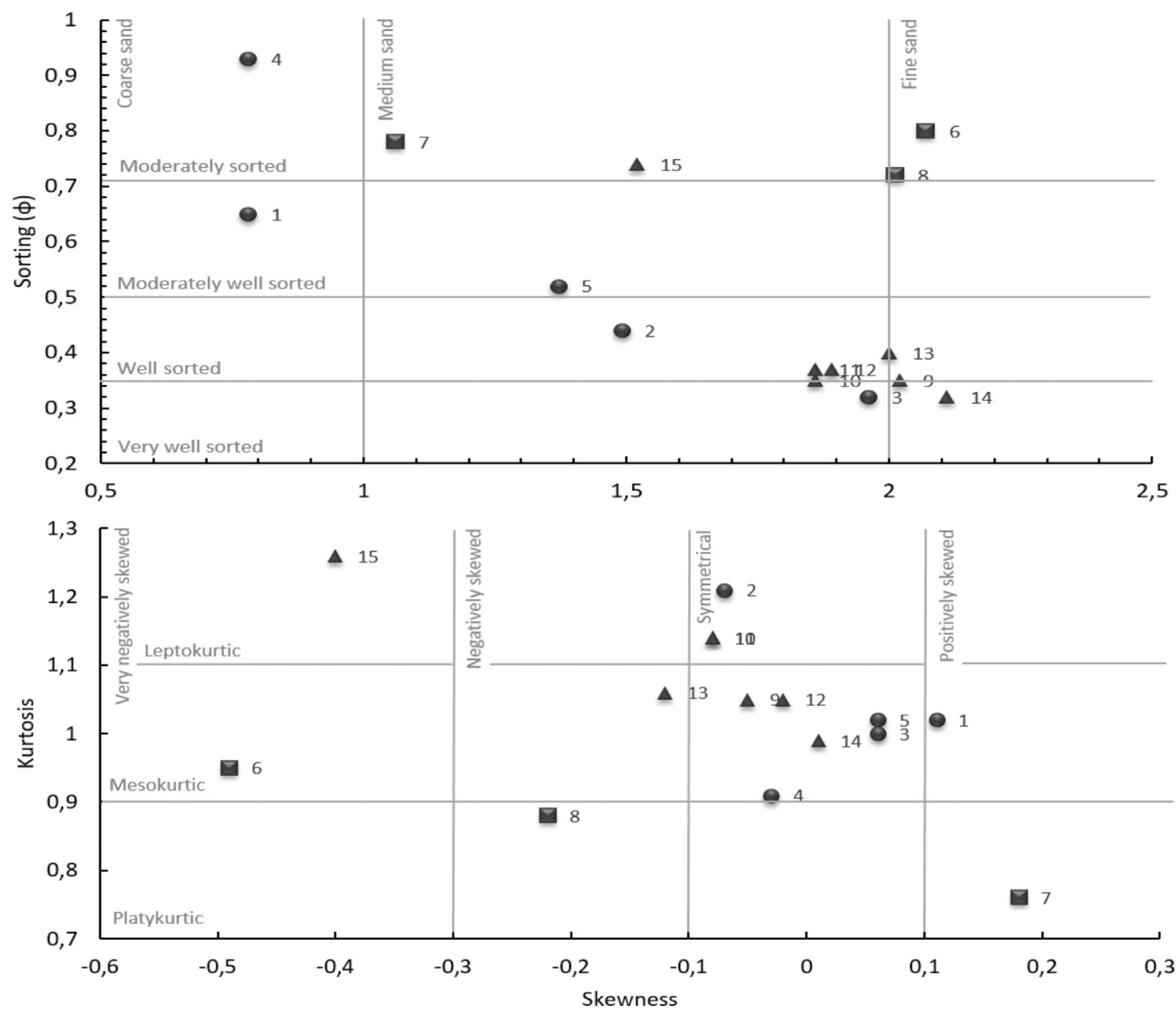

- Natural Basaltic Beaches』 Artificial Calcareous Beaches_ Natural Calcareous Beaches

Fig. 10. Plot of the statistical parameters mean diameter, sorting, skewness and kurtosis of the Madeira and Porto Santo beaches. 1 - Praia da Laje; 2 - Praia do Porto da Cruz; 3 - Prainha; 4 Praia Nova; 5 - Praia do Areeiro; 6 - Praia da Banda D'Além; 7 - Praia da Calheta (east side); 8 - Praia da Calheta (west side); 9 - Praia do Penedo; 10 - Praia da Fontinha; 11 - Praia do Ribeiro Cochino; 12 - Praia do Ribeiro Salgado; 13 - Praia do Cabeço; 14 - Praia da Lagoa; 15 - Praia da Calheta.

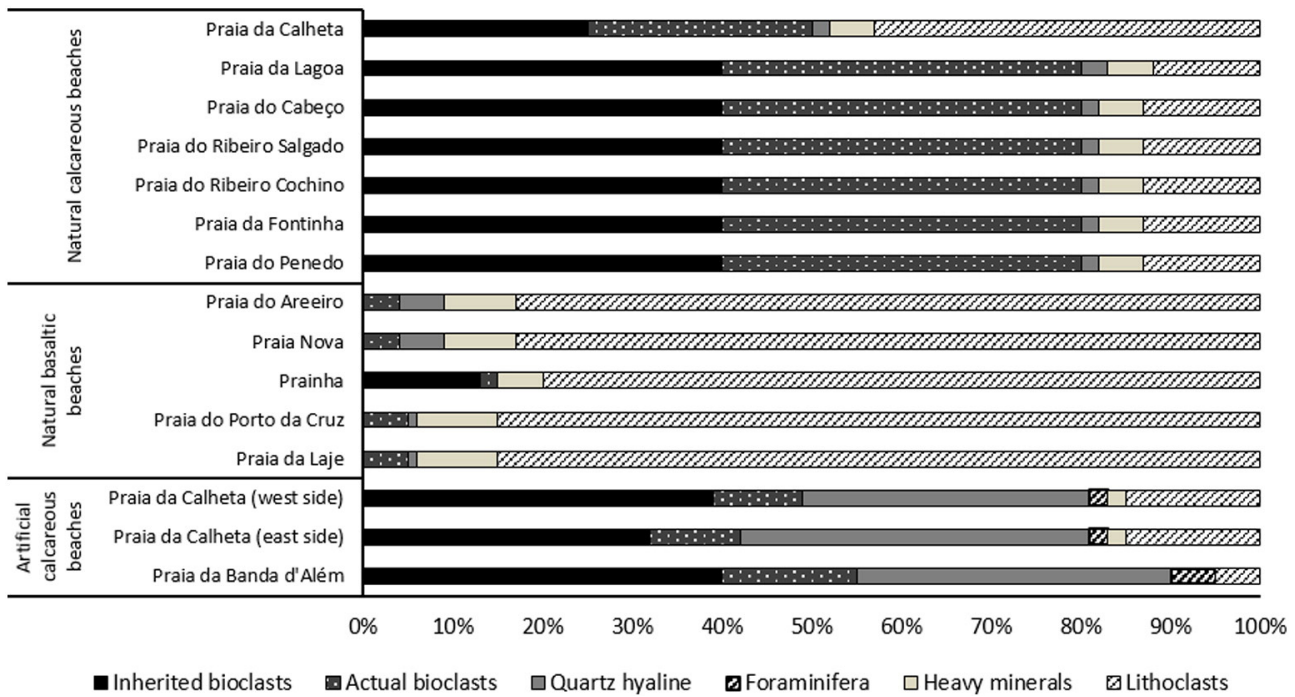

Fig. 11. Composition (in relative proportions) of the $1 \varphi$ fraction of the Madeira and Porto Santo beaches. 


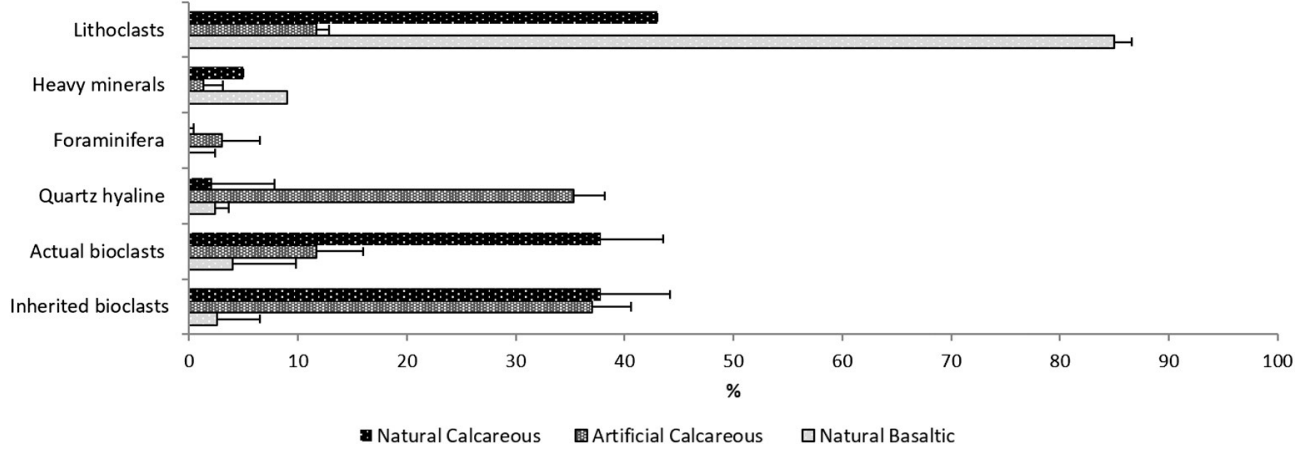

Fig. 12. Average and standard deviation of mineral content (in \%) between different types of Madeira and Porto Santo beaches.

sediments inside the semi-open pools bounded by the hard defence structures. The protection works decreased the natural dynamics of the coastal environment, providing conditions that favour microbial contamination of the sand to levels not allowed for in natural conditions. Even though hard protection structures do not influence the tidal levels, they markedly change the reach of the wave swash landward of the water line. This minimizes the "washing effect" associated with the tides, decreases sand remobilization, and, consequently, promotes lack of sand renovation that leads to higher sand contamination (Pereira et al., 2013). Bather's attendance in Madeira's artificial beaches can also be one vital reason for the higher sand contamination levels on these beaches. Indeed, the number of visitors of artificial beaches, significantly increased after completion of the placement works. The number of beachgoers in artificial beaches is also much higher when compared to natural ones, due to the attractiveness of the sand and sense of security (Pereira et al., 2013). This will create different kinds of impacts directly linked to sand microbiological contamination, such as production/accumulation of litter, direct human contact with sand, and the simple fact of feeding animals near the beach.

\section{Conclusions}

Specific management frameworks are required for beaches that have natural or artificial singularities (both due to their location and users), and especially for beaches located in high demanding touristic areas such as the Madeira Archipelago.

An atypical extreme precipitation event that occurred in 2010 was responsible for higher values of biological and mycological contaminants in Madeira sand beaches, when compared with the following years, due to the damages that occurred in sewer lines, and debris transported to the ocean shores. In the following years, the contamination levels decreased, most probably due to coastal cleaning and the repair of damaged infrastructure. This result reveals the impact that flashfloods can have on beach sand quality and that efforts to repair the damages are not only important for the improvement of water quality, but also to enhance sand quality. Along the study time frame, our results showed higher contaminant levels in artificial beaches when compared to natural ones. Taking into account several potential microbiological contamination sources, bather's attendance and the disruption of normal shore dynamics by hard protection structures in artificial beaches, were considered to be the main influencing agents of microbial contamination in Madeira and Porto Santo.

Statistical data outputs revealed no relevant links between sedimentological indicators and sand microbiological contamination, concluding that sand nature/characteristics are not relevant for sand microbiological contamination in Madeira.

The overall findings of this study deliver a valuable baseline for assessment of sand beach mycological and bacterial contaminants, and are a warning to the occurrence of potential harmful bacteria and fungi in beach sand environments. Furthermore, it gives information to beach managers on the importance of implementing a system that acknowledges beach sand as a crucial component of beach quality management.

\section{Acknowledgements}

The authors would like to acknowledge the support of the CARMAC project (MAC/2/C011) and of the Instituto Dom Luiz - IDL (UID/GEO/ 50019/2013). We wish to thank Dr. Nuno Aguiar and Dr ${ }^{\text {a }}$. Elisabete Pereira for their field and microbial laboratory work during the referred

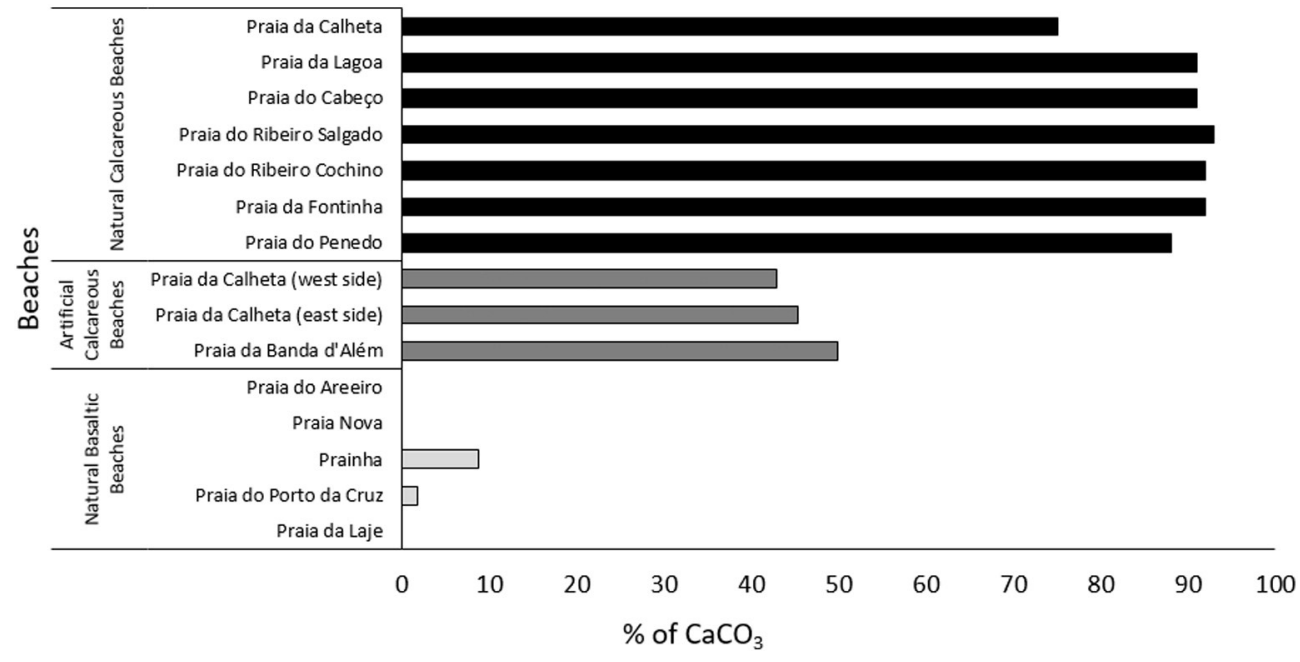

Fig. 13. $\mathrm{CaCO}_{3}$ content of the Madeira and Porto Santo beaches. 

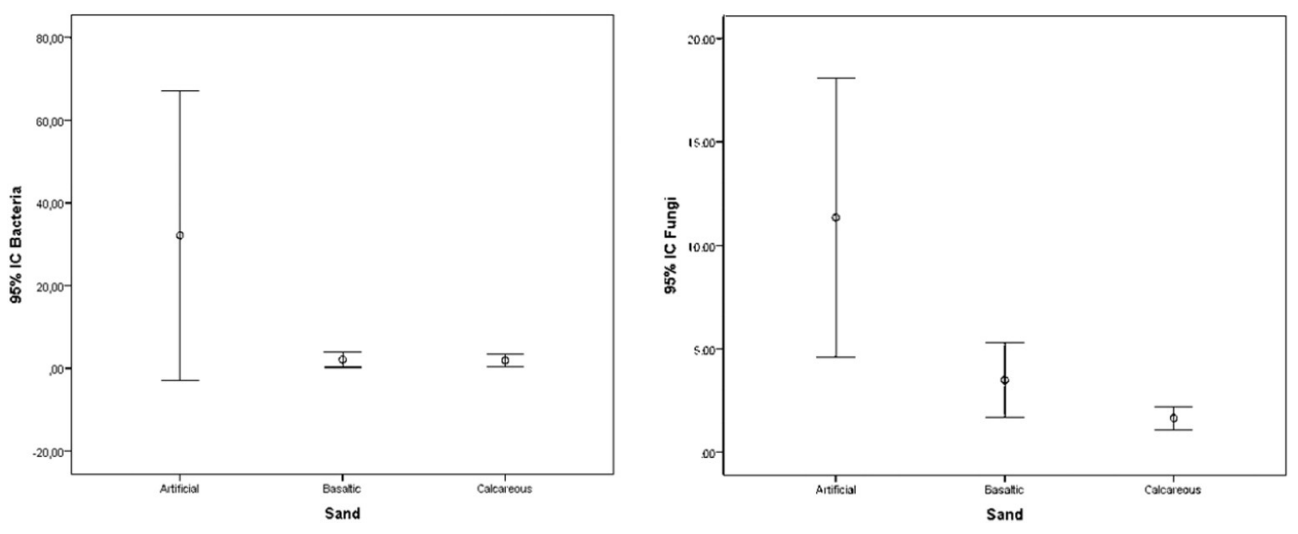

Fig. 14. Mean and standard deviation considering the three sand types.

project. Thanks are also due to the technicians of the Department of Geology (Faculty of Sciences, University of Lisbon) S. Pereira and Dr. V. Lopes, for part of the sedimentological work and to Prof. R. Taborda for the help during field work in Porto Santo.

\section{References}

Abdelzaher, A.M., Wright, M.E., Ortega, C., Solo-Gabriele, H.M., Miller, G., Elmir, S. Newman, X., Shih, H., Bonilla, J.A., Bonilla, T.D., Palmer, C.J., Scott, T., Lukasik, J. Harwood, V.J., McQuaig, S., Sinigalliano, C., Gidley, M., Plano, L.R.W., Zhu, X., Wang, J.D., Fleming, L.E., 2010. Presence of pathogens and indicator microbes at a nonpoint source subtropical recreational marine beach. Appl. Environ. Microbiol. 76 (3), 724-732. http://dx.doi.org/10.1128/AEM.02127-09.

Andrade, C., Freitas, M., Taborda, R., Prada, S., 2008. Plano de Urbanização da Frente Mar Campo de Baixo - Ponta da Calheta, Porto Santo. Caracterização e diagnóstico, Anexo 8 - Geologia e Geomorfologia Costeira, Dinâmica Costeira, Hidrogeologia. Universidade da Madeira, Faculdade de Ciências de Lisboa, Centro de Geologia da Faculdade de Ciência de Lisboa http://dx.doi.org/10.1016/j.ejsobi.2007.08.016 (104 p).

Arvanitidou, M., Kanellou, K., Katsouyannopoulos, V., Tsakris, A., 2002. Occurrence an densities of fungi from northern Greek coastal bathing waters and their relation with faecal pollution indicators. Water Res. 36 (20), 5127-5131. http://dx.doi.org/ 10.1016/S0043-1354(02)00235-X.

Azevedo, E., Figueira, D., Caeiro, M.F., Barata, M., 2010. Biodiversity of filamentous fungi on soils and sands. Progress in Mycology. Springer, Netherlands, pp. 233-257 http://dx. doi.org/10.1007/978-90-481-3713-8_8.

Bonilla, T.D., Nowosielski, K., Cuvelier, M., Hartz, A., Green, M., Esiobu, N., McCorquodale, D.S., Fleisher, J.M., Rogerson, A., 2007. Prevalence and distribution of fecal indicator organisms in South Florida beach sand and preliminary assessment of health effects associated with beach sand exposure. Mar. Pollut. Bull. 54 (9), 1472-1482. http:// dx.doi.org/10.1016/j.marpolbul.2007.04.016.

Botero, C., Pereira, C., Tosic, M., Manjarrez, G., 2014. Design of an index for monitoring the environmental quality of tourist beaches from a holistic approach. Ocean Coast. Manag. http://dx.doi.org/10.1016/j.ocecoaman.2014.07.017.

Brandão, J., Wergikosky, B., Rosado, C., 2002. Relatório final do projecto "Qualidade Microbiológica de areias de Praias Litorais". Associação Bandeira Azul da Europa.

Brum da Silveira, A., Madeira, J., Ramalho, R., Fonseca, P. E., \& Prada, S. (2010). Notícia Explicativa da Carta Geológica da Ilha da Madeira na escala 1: 50 000, Folhas A e B.

Byappanahalli, M., Fujioka, R., 2004. Indigenous soil bacteria and low moisture may limit but allow faecal bacteria to multiply and become a minor population in tropical soils. Water Sci. Technol. 50 (1), 27-32.

Carvalho, C., 1998. GranGraf V 2.0 B, Programa de Tratamento de Dados Granulométricos. F.C.U.L., Lisboa.

Craig, D.L., Fallowfield, H.J., Cromar, N.J., 2002. Enumeration of faecal coliforms from recreational coastal sites: evaluation of techniques for the separation of bacteria from sediments. J. Appl. Microbiol. 93 (4), 557-565. http://dx.doi.org/10.1046/j.1365 2672.2002.01730.x.

Czajkowski, M., 2002. A geological tour of the islands of Madeira and Porto Santo. Geol. Today 18 (1), 26-34. http://dx.doi.org/10.1046/j.1365-2451.2002.00009.x.

Dale, N.G., 1974. Bacteria in intertidal sediments: factors related to their distribution. Limnol. Oceanogr. 19 (3), 509-518. http://dx.doi.org/10.4319/lo.1974.19.3.0509.

De Carvalho, A.G. Brandão, J.M., 1991. Geologia do arquipélago da Madeira.

De Moura Sarquis, M.I., De Oliveira, P.C., 1996. Diversity of microfungi in the sandy soil of Ipanema Beach, Rio de Janeiro, Brazil. J. Basic Microbiol. 36 (1), 51-58. http://dx.doi. org/10.1002/jobm.3620360111.

Defeo, O., McLachlan, A., Schoeman, D.S., Schlacher, T.A., Dugan, J., Jones, A., Lastra, M., Scapini, F., 2009. Threats to sandy beach ecosystems: a review. Estuar. Coast. Shelf Sci. 81 (1), 1-12. http://dx.doi.org/10.1016/j.ecss.2008.09.022.

Efstratiou, M.A., Velegraki, A., 2010. Recovery of melanized yeasts from eastern Mediterranean beach sand associated with the prevailing geochemical and marine flora patterns. Med. Mycol. 48 (2), 413-415. http://dx.doi.org/10.3109/13693780902814294.
Elmir, S.M., Wright, M.E., Abdelzaher, A., Solo-Gabriele, H.M., Fleming, L.E., Miller, G., Rybolowik, M., Shih, M.P., Pillai, S.P., Cooper, J.A., Quaye, E.A., 2007. Quantitative evaluation of bacteria released by bathers in a marine water. Water Res. 41 (1), 3-10. http://dx.doi.org/10.1016/j.watres.2006.10.005.

Ferguson, D.M., Moore, D.F., Getrich, M.A., Zhowandai, M.H., 2005. Enumeration and speciation of enterococci found in marine and intertidal sediments and coastal water in southern California. J. Appl. Microbiol. 99 (3), 598-608. http://dx.doi.org/10.1111/j. 1365-2672.2005.02660.x.

Ferreira, C.W.F., de Sousa, F., C., J., 2000. Microbiologia. Sol 2. Lidel, Lisboa.

Fleisher, J.M., Fleming, L.E., Solo-Gabriele, H.M., Kish, J.K., Sinigalliano, C.D., Plano, L., Elmir, S.M., Wang, J.D., Withum, K., Shibata, T., Gidley, M.L., Abdelzaher, A., He, G., Ortega, C., Zhu, X., Wright, M., Hollenbeck, J., Backer, L.C., 2010. The BEACHES study: health effects and exposures from non-point source microbial contaminants in subtropical recreational marine waters. Int. J. Epidemiol. 39 (5), 1291-1298. http://dx.doi.org/ 10.1093/ije/dyq084.

Folk, R.L., Ward, W.C., 1957. Brazos River bar: a study in the significance of grain-size parameters. J. Sediment. Res. 27 (1), 3-26.

Friedman, G.M., Sanders, J.E., 1978. Principles of Sedimentology. Wiley, New York (792p).

Gast, R.J., Gorrell, L, Raubenheimer, B. Elgar, S., 2011. Impact of erosion and accretion on the distribution of enterococci in beach sands. Cont. Shelf Res. 31 (14), 1457-1461. http://dx.doi.org/10.1016/j.csr.2011.06.011.

Gomes, D., Cavalcanti, M.A.Q., Fernandes, M.J.S., Lima, D.M.M., Passavante, J.Z.O., 2008. Filamentous fungi isolated from sand and water of "Bairro Novo" and "Casa Caiada" beaches, Olinda, Pernambuco, Brazil. Braz. J. Biol. 68 (3), 577-582. http://dx.doi.org/ 10.1590/S1519-69842008000300016.

Goodwin, K.D., McNay, M., Cao, Y., Ebentier, D., Madison, M., Griffith, J.F., 2012. A multibeach study of Staphylococcus aureus, MRSA, and enterococci in seawater and beach sand. Water Res. 46 (13), 4195-4207. http://dx.doi.org/10.1016/j.watres.2012.04. 001.

Haller, L, Poté, J, Loizeau, J.L., Wildi, W, 2009. Distribution and survival of faecal indicator bacteria in the sediments of the Bay of Vidy, Lake Geneva, Switzerland. Ecol. Indic. 9 (3), 540-547. http://dx.doi.org/10.1016/j.ecolind.2008.08.001.

Hartz, A., Cuvelier, M., Nowosielski, K., Bonilla, T.D., Green, M., Esiobu, N., McCorquodale, D.S., Rogerson, A., 2008. Survival potential of and enterococci in subtropical beach sand: implications for water quality managers. J. Environ. Qual. 37 (3), 898-905. http://dx.doi.org/10.2134/jeq2007.0312.

Heaney, C.D., Sams, E., Wing S., Marshall, S., Brenner, K., Dufour, A.P. Wade, TJ, 2009. Contact with beach sand among beachgoers and risk of illness. Am. J. Epidemiol. 170 (2), 164-172. http://dx.doi.org/10.1093/aje/kwp152.

Heaney, C.D., Sams, E., Dufour, A.P., Brenner, K.P., Haugland, R.A., Chern, E., Wing, S., Marshall, S., Love, D.C., Serre, M., Noble, R., Wade, T.J., 2012. Fecal indicators in sand, sand contact, and risk of enteric illness among beachgoers. Epidemiology 23 (1), 95. http://dx.doi.org/10.1097/EDE.0b013e31823b504c.

Hernandez, R.J., Hernandez, Y. Jimenez, N.H., Piggot, A.M., Klaus, J.S., Feng, Z., Reniers, A Solo-Gabriele, H.M., 2014. Effects of full-scale beach renovation on fecal indicator levels in shoreline sand and water. Water Res. 48, 579-591. http://dx.doi.org/10. 1016/j.watres.2013.10.020

Ishii, S., Hansen, D.L., Hicks, R.E., Sadowsky, M.J., 2007. Beach sand and sediments are temporal sinks and sources of Escherichia coli in Lake Superior. Environ. Sci. Technol. 41 (7), 2203-2209. http://dx.doi.org/10.1021/es0623156.

Johnson, M.E da Silva, C.M Santos, A, Baarli, B.G Cachão, M. Mayoral, EJ Rebelo, A.C. Ledesma-Vázquez, J., 2011. Rhodolith transport and immobilization on a volcanically active rocky shore: middle Miocene at Cabeço das Laranjas on Ilhéu de Cima (Madeira Archipelago, Portugal). Palaeogeogr. Palaeoclimatol. Palaeoecol. 300 (1), 113-127. http://dx.doi.org/10.1016/j.palaeo.2010.12.014.

Kaštelan, M., Utješinovic-Gudelj, V., Prpić-Massari, L., Brajac, I., 2014. Dermatophyte infections in Primorsko-Goranska County, Croatia: a 21-year survey. Acta Dermatovenerol. Croat. 22 (3), 175.

Khan, I.U., Hill, S., Nowak, E., Edge, T.A., 2013. Effect of incubation temperature on the detection of thermophilic Campylobacter species from freshwater beaches, nearby wastewater effluents, and bird fecal droppings. Appl. Environ. Microbiol. 79 (24), 7639-7645. http://dx.doi.org/10.1128/AEM.02324-13.

Lee, C.M., Lin, T.C., Lin, C., Kohbodi, G.A., Bhatt, A., Lee, R., Jay, J.A., 2006. Persistence of fecal indicator bacteria in Santa Monica Bay beach sediments. Water Res. 2593-2602. 
Mansilha, C.R., Coelho, C.A., Heitor, A.M., Amado, J., Martins, J.P., Gameiro, P., 2009. Bathing waters: new directive, new standards, new quality approach. Mar. Pollut. Bull. 58 (10), 1562-1565. http://dx.doi.org/10.1016/j.marpolbul.2009.03.018.

Mika, K.B., Imamura, G., Chang, C., Conway, V., Fernandez, G., Griffith, J.F., Kampalath, R.A., Lee, C.M., Lin, C.C., Moreno, R., Thompson, S., Whitman, R.L., Jay, J.A., 2009. Pilot-and bench-scale testing of faecal indicator bacteria survival in marine beach sand near point sources. J. Appl. Microbiol. 107 (1), 72-84. http://dx.doi.org/10.1111/j.13652672.2009.04197.x

Moreno, M., Ferrero, T.J., Granelli, V., Marin, V., Albertelli, G., Fabiano, M., 2006. Across shore variability and trophodynamic features of meiofauna in a microtidal beach of the NW Mediterranean. Estuar. Coast. Shelf Sci. 66 (3), 357-367. http://dx.doi.org/ 10.1016/j.ecss.2005.08.016

Pereira, E., Figueira, C., Aguiar, N., Vasconcelos, R., Vasconcelos, S., Calado, G., Brandão, J., Prada, S., 2013. Microbiological and mycological beach sand quality in a volcanic environment: Madeira archipelago, Portugal. Sci. Total Environ. 461, 469-479. http://dx. doi.org/10.1016/j.scitotenv.2013.05.025.

Phillips, M.C., Solo-Gabriele, H.M., Piggot, A.M., Klaus, J.S., Zhang, Y., 2011. Relationships between sand and water quality at recreational beaches. Water Res. 45 (20), 6763-6769. http://dx.doi.org/10.1016/j.watres.2011.10.028.

Piggot, A.M., Klaus, J.S., Johnson, S., Phillips, M.C., Solo-Gabriele, H.M., 2012. Relationship between enterococcal levels and sediment biofilms at recreational beaches in South Florida. Appl. Environ. Microbiol. 78 (17), 5973-5982. http://dx.doi.org/10.1128/ AEM.00603-12.

Plano, L.R., Garza, A.C., Shibata, T., Elmir, S.M., Kish, J., Sinigalliano, C.D., Gidley, M.L., Miller, G., Withum, K., Fleming, L.E., Solo-Gabriele, H.M., 2011. Shedding of Staphylococcus aureus and methicillin-resistant Staphylococcus aureus from adult and pediatric bathers in marine waters. BMC Microbiol. 11 (1), 5. http://dx.doi.org/10.1186/14712180-11-5.

Pond, K., 2005. Water Recreation and Disease: Plausibility of Associated Infections: Acute Effects, Sequelae and Mortality. IWA Publishing on behalf of the World Health Organization, London.

Resell, G., Taplin, D., 1970. Dermatophytes. Their recognition and identification. Dermatophytes. Their Recognition and Identification (Revised edition).

Sabino, R., Veríssimo, C., Cunha, M.A., Wergikoski, B., Ferreira, F.C., Rodrigues, R., Parada, H., Falcão, L., Rosado, L., Pinheiro, C., Paixão, E., Brandão, J., 2011. Pathogenic fungi: an unacknowledged risk at coastal resorts? New insights on microbiological sand quality in Portugal. Mar. Pollut. Bull. 62 (7), 1506-1511. http://dx.doi.org/10.1016/j. marpolbul.2011.04.008.

Sabino, R., Rodrigues, R., Costa, I., Carneiro, C., Cunha, M., Duarte, A., Faria, N., Ferreira, F.C. Gargaté, M.J., Júlio, C., Martins, M.L., Nevers, M.B., Oleastro, M., Solo-Gabriele, H., Veríssimo, C., Viegas, C., Whitman, R.L., Brandão, J., 2014. Routine screening of harmful microorganisms in beach sands: implications to public health. Sci. Total Environ. 472, 1062-1069. http://dx.doi.org/10.1016/j.scitotenv.2013.11.091.

Salvo, V.S., Fabiano, M., 2007. Mycological assessment of sediments in Ligurian beaches in the northwestern Mediterranean: pathogens and opportunistic pathogens. J. Environ. Manag. 83 (3), 365-369. http://dx.doi.org/10.1016/j.jenvman.2006.04.001.

Sessisch, A., Weilharter, A., Gerzabek, M.H., Kirchmann, H., Kandeler, E., 2001. Microbial population structures in soil particle size fractions of a long-term fertilizer field experiment. Appl. Environ. Microbiol. 67, 4215-4224. http://dx.doi.org/10.1128/AEM. 67.9.4215-4224.2001.

Shah, A.H., Abdelzaher, A.M., Phillips, M., Hernandez, R., Solo-Gabriele, H.M., Kish, J., Scorzetti, G., Fell, J.W., Diaz, M.R., Scott, T.M., Lukasik, J., Harwood, V.J., McQuaig, S., Sinigalliano, C.D., Gidley, M.L., Wanless, D., Ager, A., Lui, J., Stewart, J.R., Plano, L.R.W., Fleming, L.E., 2011. Indicator microbes correlate with pathogenic bacteria, yeasts and helminthes in sand at a subtropical recreational beach site. J. Appl. Microbiol. 110 (6), 1571-1583. http://dx.doi.org/10.1111/j.1365-2672.2011.05013.x.

Sharaf, E.F., 2005. A potent chitinolytic activity of Alternaria alternata isolated from Egyptian black sand. Pol. J. Microbiol. 54 (2), 145.

Shibata, T., Solo-Gabriele, H.M., 2012. Quantitative microbial risk assessment of human illness from exposure to marine beach sand. Environ. Sci. Technol. 46 (5), 2799-2805. http://dx.doi.org/10.1021/es203638x.

Sinigalliano, C.D., Fleisher, J.M., Gidley, M.L., Solo-Gabriele, H.M., Shibata, T., Plano, L.R., Elmir, S.M., Wanless, D., Bartkowiak, J., Boiteau, R., Withum, K., Abdelzaher, A.M.,
He, G., Ortega, C., Zhu, X., Wright, M.E., Kish, J., Hollenbeck, J., Scott, T., Backer, L.C., Fleming, L.E., 2010. Traditional and molecular analyses for fecal indicator bacteria in non-point source subtropical recreational marine waters. Water Res. 44 (13), 3763-3772. http://dx.doi.org/10.1016/j.watres.2010.04.026.

Skalbeck, J.D., Kinzelman, J.L., Mayer, G.C., 2010. Fecal indicator organism density in beach sands: impact of sediment grain size, uniformity, and hydrologic factors on surface water loading. J. Great Lakes Res. 36 (4), 707-714. http://dx.doi.org/10.1016/j.jglr 2010.08.004.

Solo-Gabriele, H.M., Harwood, V.J., Kay, D., Fujioka, R.S., Sadowsky, M.J., Whitman, R.L., Wither, A., Caniça, M., Fonseca, R.C., Duarte, A., Edge, T.A., Gargaté, M.J., GundeCimerman, N., Hagen, F., Mclellan, S.L., Da Silva, A.N., Babič, M.N., Prada, S., Rodrigues, R., Romão, D., Sabino, R., Samson, R.A., Segal, E., Staley, C., Taylor, H.D. Veríssimo, C., Viegas, C., Barroso, H., Brandão, J.C., 2015. Beach sand and the potential for infectious disease transmission: observations and recommendations. J. Mar. Biol. Assoc. U. K. 1-20 http://dx.doi.org/10.1017/S0025315415000843.

Turismo de Portugal, I.P., 2015. Número de noites efetuadas por um indivíduo num estabelecimento que fornece alojamento, por um período compreendido entre as 12 horas de um dia e as 12 horas do dia seguinte. Indicador por NUTS II, por Mercados e por Tipologia. http://www.turismodeportugal.pt/portugu\%C3\%AAs/proturismo/ estat\%C3\%ADsticas/quadrosestatisticos/dormidas/pages/dormidas.aspx Accessed on June $11,2015$.

Ulfig, K., Guarro, J., Cano, J., Gene, J., Vidal, P., Figueras, M.J., 1997. General assessment of the occurrence of keratinolytic fungi in river and marine beach sediments of Catalonian waters (Spain). Water Air Soil Pollut. 94 (3-4), 275-287. http://dx.doi.org/10. 1007/BF02406063.

Velonakis, E., Dimitriadi, D., Papadogiannakis, E., Vatopoulos, A., 2014. Present status of effect of microorganisms from sand beach on public health. J. Coast. Life Med. 2 (9), 746-756. http://dx.doi.org/10.12980/JCLM.2.2014JCLM-2014-0067.

Vogel, C., Rogerson, A., Schatz, S., Laubach, H., Tallman, A., Fell, J., 2007. Prevalence of yeasts in beach sand at three bathing beaches in South Florida. Water Res. 41 (9), 1915-1920. http://dx.doi.org/10.1016/j.watres.2007.02.010.

Wang, X., Singh, P., Gao, Z., Zhang, X., Johnson, I.Z., Wang, G., 2014. Distribution and diversity of planctonic fungi in the west pacific warm pool. PLoS One 9. http://dx.doi.org/ 10.1371/journal.pone.0101523.

Whitman, R.L., Nevers, M.B., 2003. Foreshore sand as a source of Escherichia coli in nearshore water of a Lake Michigan beach. Appl. Environ. Microbiol. 69 (9), 5555-5562. http://dx.doi.org/10.1128/AEM.69.9.5555-5562.2003.

Whitman, R.L., Harwood, V.J., Edge, T.A., Nevers, M.B., Byappanahalli, M., Vijayavel, K., Brandão, J., Sadowsky, J., Alm, E.W., Crowe, A., Ferguson, D., Ge, Z., Halliday, E., Kinzelman, J., Kleinheinz, G., Przybyla-Kelly, K., Staley, C., Staley, Z., Solo-Gabriele, H.M., 2014. Microbes in beach sands: integrating environment, ecology and public health. Rev. Environ. Sci. Biotechnol. 13 (3), 329-368. http://dx.doi.org/10.1007/ s11157-014-9340-8.

Wright, M.E., Solo-Gabriele, H.M., Elmir, S., Fleming, L.E., 2009. Microbial load from animal faeces at a recreational beach. Mar. Pollut. Bull. 58 (11), 1649-1656. http://dx.doi.org/ 10.1016/j.marpolbul.2009.07.003.

Yamahara, K.M., Layton, B.A., Santoro, A.E., Boehm, A.B., 2007. Beach sands along the California coast are diffuse sources of fecal bacteria to coastal waters. Environ. Sci. Technol. 41 (13), 4515-4521. http://dx.doi.org/10.1021/es062822n.

Yamahara, K.M., Sassoubre, L.M., Goodwin, K.D., Boehm, A.B., 2012. Occurrence and persistence of bacterial pathogens and indicator organisms in beach sand along the California coast. Appl. Environ. Microbiol. 78 (6), 1733-1745. http://dx.doi.org/10.1128/ AEM.06185-11.

Zehms, T.T., McDermott, C.M., Kleinheinz, G.T., 2008. Microbial concentrations in sand and their effect on beach water in Door County, Wisconsin. J. Great Lakes Res. 34 (3), 524-534. http://dx.doi.org/10.3394/0380-1330(2008)34[524:MCISAT]2.0.CO;2.

Zhang, Q., He, X., Yan, T. 2015. Differential decay of wastewater bacteria and change of microbial communities in beach sand and seawater microcosms. Environ. Sci. Technol. 49 (14), 8531-8540. http://dx.doi.org/10.1021/acs.est.5b01879.

Zhu, X., Wang, J.D., Solo-Gabriele, H.M., Fleming, L.E., 2011. A water quality modelling study of non-point sources at recreational marine beaches. Water Res. 45 (9), 2985-2995. http://dx.doi.org/10.1016/j.watres.2011.03.015. 